\title{
IAMJ
}

INTERNATIONAL

AYURVEDIC

MEDICAL JOURNAL

ISSN: 23205091

Impact Factor: 5.34

\section{PHARMACEUTICO-ANALYTICAL STUDY OF ADITYAPAKA GUDUCHITAILA W.S.R TO ADITYAPAKA METHOD}

\section{Bankimchandra S. Jambagi ${ }^{1}$, Vijaykumar Chavadi}

${ }^{1}$ Final year PG Scholar, ${ }^{2}$ Associate Professor,

P.G. Department of Rasa shastra and Bhaishajya Kalpana, BVVS Ayurveda Medical College and Hospital, Bagalkot, Karnataka, India

Corresponding Author: bsjambagi26@,gmail.com

https://doi.org/10.46607/iamj1808092020

(Published online: September 2020)

Open Access

(C) International Ayurvedic Medical Journal, India 2020

Article Received: 01/09/2020 - Peer Reviewed: 08/09/2020 - Accepted for Publication: 08/09/2020

Check for updates

\begin{abstract}
Purpose: Taila Kalpana is one of Sneha Kalpana procedure which is widely used and mostly preferred dosage forms of Ayurvedic system of medicine. It is followed to produce an oleaginous medicament from. Taila Kalpana involves 2 methods viz, Agnipakavidhi and Adityapakavidhi. Agnipakavidhi(Heating through Fire) is a method where fire is used as source to prepare the medicine Adityapakavidhi (Heating through sunlight), where the preparation is subjected to intense heat from Sun rays until the Taila Siddhi Lakshana (Tests of perfection) are observed, Adityapaka Guduchi Taila is selected for study to Pharmaceutical as well as Analytical parameters the results obtained are differed as compared with Agnipaka Vidhi Siddha Taila due to its unique method of preparation.
\end{abstract}

Keywords: Adityapaka Vidhi, Taila Kalpana, Adityapaka Guduchi Taila,

\section{INTRODUCTION}

Ayurveda being ancient system of medicine having uniqueness and diversity of preparation to eradicate the diseases and also to maintain the health. Rasashastra and Bhaishajya Kalpana is the greatest contribution to Ayurveda. Acharya Charaka has described primary dosages forms i.e. Swarasa (Juice), Kalka (Paste), Kwatha (Decoction), Hima (Cold infusion) \& Phanta
(Hot infusion) and mentioned them as Panchavidha Kashaya Kalpana (5 types of Primary preparations). Keeping these as the basic preparations, number of secondary preparations have been derived from these five preparations viz. Asavarishta (Fermentation), Lepa (Paste), Churna (Powder), Sneha Kalpana (Fatty preparation), Vati (Pills) etc Sneha Kalpana is well known 
among them. Taila Kalpana is one of Sneha Kalpana procedure which is widely used and mostly preferred dosage forms of Ayurvedic system of medicine. It is followed to produce an oleaginous medicament from. The substances such as Kalka, Kwatha, and Drava Dravyas, in specific proportions by subjecting them to a specified heating pattern and duration will get converted into potent medicament. By this process, one can ensure transformation of the active therapeutic properties of the ingredients to the solvents and hence, one can recover fat-soluble as well as water-soluble chemical constituents. Taila Kalpana involves 2 methods 1 . Agnipakavidhi (Heating through fire) 2. Adityapakavidhi (Heating through sunlight). Agnipakavidhi is a method where fire is used as source to prepare the medicine, due to its flexibility it is the most common method to prepare the most of preparations. Another one is Adityapakavidhi, where the preparation is subjected to intense heat from Sun rays until the Taila Siddhi Lakshana (Test of perfection) are observed, this kind of preparations are used only external application purpose and very effective in Skin disorders, hair and scalp areas. this Adityapaka Sneha absorbs the UV rays from sun, the sun's Ultraviolet rays are made up of UVA and UVB rays. UVB rays are more effective at treating skin disorders because they penetrate more and helps for rapid skin shedding and growth ${ }^{1}$. It helps to reduce the inflammation of skin. So, the analytical study is time in need to prove the surprise results of $A d$ ityapaka Vidhi, Adityapaka Guduchi Taila is one such preparation which is mentioned in Bhaishajya Ratnavali $^{2}$ specially for Khalitya (Hair fall). Adityapaka Guduchi Taila is prepared as per the $A d$ ityapaka Vidhi and various analysis are done to know the efficacy of Adityapaka Vidhi.

\section{Objectives}

1. Preparation and Pharmaceutical observations on Adityapaka Guduchi Taila.

2. Analytical Study of Aditypaka Guduchi Taila.

Materials and Methods:

Pharmaceutical Study of Adityapaka Guduchitaila:

Table 1: Ingredients:

\begin{tabular}{|l|l|l|l|l|l|}
\hline Sl.No & Drug & Latin Name and Family & Role as & Part Used & Quantity \\
\hline 1 & Guduchi & Tinospora cordifolia /Menispermaceae & Drava dravya & Panchanga & 5 Litters \\
\hline 2 & Vata & Ficus bengalensis /Moraceae & Kalka dravya & Arial roots & $1.25 \mathrm{~kg}$ \\
\hline 3 & Jatamansi & Nardostachys jatamansi/ Valerianaceae & Kalka dravya & Tubers & $1.25 \mathrm{~kg}$ \\
\hline 4 & Tila & Sesamum indicum /Pedaliaceae & Sneha dravya & Seeds & 5 Litters \\
\hline
\end{tabular}

\section{Steps Involved:}

- Collection of the raw materials.

- Preparation of Guduchi Swarasa.

- Preparation of Jatamansi and Vatapraroha Kalka.

- Mixing it with Moorchita Tilataila.

- Keeping in the sunlight.

Selection and Collection of the raw materials: Fresh Stem and leaves of Guduchi, Ariel's roots of Vata are collected from a garden, Moorchita Tila Taila and Roots of Jatamansi are procured from the BVVS Ayurveda Pharmacy, all ingredients are selected after proper authentication by experts in the Dravyaguna department of the institution, taken quantities are tabulated in Table No. 1.
Preparation of Guduchi Swarasa ${ }^{3}$ (Fig no.1 \& 4):

Ingredients: Freshly collected Guduchi Plant (Stem and Leaves)

Pre-Procedure: Fresh Guduchi leaves are collected and cleaned with water, then made them into paste form by pounding in Khalwa-yantra, then juice is extracted by squeezing it with through a double layered cotton cloth. Thus, obtained juice is Guduchi Swarasa.

Preparation of Jatamansi and Vatapraroha Kalka (Fig. No. 5 \& 6): Fresh wet drugs of Vatapraroha and Jatamansi root are collected and cleaned with water and made into paste in the Khalva-yantra.

Preparation of Adityapaka Guduchi Taila ${ }^{5}$ (Fig No. 7 to 12): In a broad mouthed stainless steel vessel, the extracted juice of Guduchi 1part is poured and equal 
quantity of Moorchita Tila Taila is added after that the prepared Kalka of Jatamansi and Vatapraroha taken $1 / 4$ th part then it is mixed homogeneously kept exposed to sunlight ${ }^{5}$ and stirred frequently to facilitate the absorption of active principles of Guduchi, Vatapraroha and Jatamansi into the Taila media. After proper mixing, it is kept in a place where complete sun rays fall on that and the procedure of stirring is continued for every 1 hours so that the complete evaporation of water molecules takes place during Aditya Pakavidhi and Taila Siddhi Lakshanas are observed.

\section{Observation and Results:}

Table 2: Observations on Pharmaceutical Study

\begin{tabular}{|c|c|c|}
\hline Sl. No. & Day & Observations \\
\hline 1. & $1^{\text {st }}$ Day & $\begin{array}{l}\text { On stirring Suspended Vatapraroha and Jatamansi in Guduchiswarasa and tila taila was clearly visible. } \\
\text { Color: Light green and dark Brown color } \\
\text { Smell: Smell of guduchi Swarasa and Jatamansi. }\end{array}$ \\
\hline 2. & $5^{\text {th }}$ Day & $\begin{array}{l}\text { Amount of fresh Guduchi Swarasa was reduced. } \\
\text { Color: Guduchi Swarasa turned from light green color to Green color } \\
\text { Smell: Guduchi and Jatamansi smell. }\end{array}$ \\
\hline 3. & $\begin{array}{l}10^{\text {th }} \\
\text { Day }\end{array}$ & $\begin{array}{l}\text { Watery bubbles in vessel with light brown Guduchi Swarasa in contact with Tilataila. } \\
\text { Color: brownish green color, Smell: Light pungent smell }\end{array}$ \\
\hline 4. & $\begin{array}{l}20^{\text {th }} \\
\text { Day }\end{array}$ & $\begin{array}{l}\text { Water quantity reduced little bit, Guduchi Swarasa turned from light color to dark color } \\
\text { Color: Brownish green color., Smell: Pungent }\end{array}$ \\
\hline 5. & $\begin{array}{l}30^{\text {th }} \\
\text { Day }\end{array}$ & $\begin{array}{l}\text { Total quantity of preparation reduced to half, sticky glue-like substance forming at bottom } \\
\text { Color: Brown color, Smell: Jatamansi dominant pungent smell }\end{array}$ \\
\hline 6. & $\begin{array}{l}40^{\text {th }} \\
\text { Day }\end{array}$ & $\begin{array}{l}\text { Less of water, More of Taila in preparation, dark glue-like substance settled at bottom of the vessel } \\
\text { Color: Brown color, Smell: Jatamansi dominant pungent smell }\end{array}$ \\
\hline 7. & $\begin{array}{l}50^{\text {th }} \\
\text { Day }\end{array}$ & $\begin{array}{l}\text { Taila with thick consistency, Kalka stick to the bottom. } \\
\text { Shabdahino Agninikshepa was Negative } \\
\text { Color: Dark brown color, Smell: Punget smell reduced, Ughragandha of Jatamansi was started to ap- } \\
\text { pear. }\end{array}$ \\
\hline 8. & $\begin{array}{l}55^{\text {th }} \\
\text { Day }\end{array}$ & $\begin{array}{l}\text { Taila with thick consistency, Kalka stick to the bottom. } \\
\text { Shabda Hino Agni Nikshepa was Positive } \\
\text { Color: Dark brown Color, Smell: Punget smell reduced, Ugragandha of Jatamansi persists. }\end{array}$ \\
\hline
\end{tabular}

Table 3: Showing duration of Paka, yield of APGT, and \% of loss in gravimetric as well as volumetric form.

\begin{tabular}{|l|l|l|l|l|l|l|l|l|l|}
\hline Name of Taila & Duration of Paka & $\begin{array}{l}\text { Initial vol- } \\
\text { ume of oil in } \\
\mathrm{ml}\end{array}$ & $\begin{array}{l}\text { Final } \\
\text { yield of } \\
\text { oil in ml }\end{array}$ & $\begin{array}{l}\text { Initial } \\
\text { weight of } \\
\text { oil in gm }\end{array}$ & $\begin{array}{l}\text { Final } \\
\text { yield of } \\
\text { oil in gm }\end{array}$ & $\begin{array}{l}\% \text { loss } \\
\text { of oil in } \\
\text { ml }\end{array}$ & $\begin{array}{l}\text { loss } \\
\text { of oil } \\
\text { in gm }\end{array}$ \\
\hline Adityapaka Guduchi Taila & 55 days & 5200 & 4100 & 6200 & 5250 & $11 \%$ & $9.5 \%$ \\
\hline
\end{tabular}


Observations and Results of Analytical Study:

Table 4: Organoleptic Characters of Adityapaka Guduchi Taila:

\begin{tabular}{|l|l|l|l|l|l|}
\hline Sl.No & Name of Preparation & Colour & Odour & Taste & Form \\
\hline 1. & Adityapaka Guduchi Taila & Rusty Orange & Jatamansi odour & Bitter & Oil \\
\hline
\end{tabular}

Refractive Index ${ }^{6}$ (Fig. No. 13):

The refractive index (n) of a substance with reference to air is the ratio of the sine of the angle of incidence to the sine of the angle of refraction of a beam of light passing from air into the substance. It varies with the wavelength of the light used in its measurement.

- Refractive Index of APGT: 1.4660

Specific Gravity ${ }^{7}$ (Fig. No. 14):: Specific gravity is the specific gravity of a liquid is the weight of a given volume of the liquid at 25o (unless otherwise specified) compared with the weight of an equal volume of water at the same temperature, all weighing are being taken in air.

- Specific gravity: 0.912

Determination of Saponification Value ${ }^{8}$ (Fig. No. 17): The saponification value is the number of $\mathrm{mg}$ of potassium hydroxide required to neutralize the fatty acids, resulting from the complete hydrolysis of $1 \mathrm{~g}$ of the oil or fat.

Formula:

Saponification Value $=\frac{(\mathrm{b}-\mathrm{a}) \times 0.02805 \times 1.000}{\mathrm{~W}}$

Where ' $\mathrm{W}$ ' is the weight in $\mathrm{g}$ of the substance taken.

Adityapaka Guduchi Taila: a- 16.4., b-27.5., W-2.039 gm.

- Saponification value of Aditya Paka Guduchi Taila: 152.69

\section{Determination of Iodine Value'(Fig. No.15):}

The Iodine value of a substance is the weight of iodine absorbed by 100 parts by weight of the substance, $(b-a) \times 0.01269 \times 100$

Iodine value $=$

$\mathrm{W}$

Adityapaka Guduchi Taila: a- 27.6., b- 38.8. W- 0.251.

- Iodine Value of APGT: 56.624

Determination of Acid Value ${ }^{10}$ (Fig. No.16): The acid value is the number of $\mathrm{mg}$ potassium hydroxide required to neutralize the free acid in $1 \mathrm{~g}$ of the substance, formula:

$$
\mathrm{a} \times 0.00561 \times 1000
$$

Acid Value $=$

$\mathrm{W}$

Where ' $a$ ' is the number of $\mathrm{ml}$. of $0.1 \mathrm{~N}$ potassium hydroxide required and ' $w$ ' is the weight in $g$ of the substance taken.

Adityapaka Guduchi Taila: a- 49.3., W - 5.076

- Acid Value: 54.496

Rancidity test (Kreis Test) ${ }^{11}$ (Fig. No. 17):

The test depends upon the formation of a red colour when oxidized fat is treated with conc. $\mathrm{HCl}$ and a solution of phloroglucinol in ether. The compound in rancid fats responsible for the colour reaction is epihydrin aldehyde. All oxidized fats respond to the Kreis test and the intensity of the colour produced is roughly proportional to the degree of oxidative rancidity.

Adityapaka Guduchi Taila: Slightly Oxidised.

HPTLC ${ }^{12}$ (Fig. 18): It was done in solvent system Toluene Ethyl Acetate, HPTLC Study of APGT shows 8 Rf value in Short UV and 5 in Long UV and 2 after derivatization. 
Table 5: HPTLC study of APGT

\begin{tabular}{|c|c|c|c|}
\hline Sl.No & Short UV & Long UV & After derivatisation \\
\hline 1. & 0.08 (Green) & - & - \\
\hline 2. & 0.31 (Green) & - & - \\
\hline 3. & 0.35 (Green) & 0.35 (F. blue) & - \\
\hline 4. & 0.46 (Green) & - & - \\
\hline 5. & - & 0.51 (F aqua blue) & - \\
\hline 6. & 0.55 (Green) & - & 0.55 (Purple) \\
\hline 7. & - & 0.59 (F. blue) & - \\
\hline 8. & 0.61 (Green) & - & - \\
\hline 9. & 0.65 (Green) & - & 0.65 (Pink) \\
\hline 10. & - & 0.73 (F. blue) & - \\
\hline 11. & 0.88 (Green) & 0.88 (F. blue) & - \\
\hline
\end{tabular}

\section{DISCUSSION}

Adityapaka Vidhi (Heating through sunlight) is one of the unique Pharmaceutical procedure of Sneha Kalpana (Oleaginous Medicament), where the uniform temperature from the Sun-rays for longer duration are utilized for the purpose of Shena Paka this allows volatile and High temperature non-stable active ingredients to imbibe completely into the preparation and show their clinical efficacy. Pharmaceutical study of Adityapaka Guduchi Taila revealed that, for complete appearance of Taila Siddhi Lakshana (Test of perfection) through Adityapaka Vidhi (Heating through sunlight) requires longer duration, as heat from the Sun is sustained and less amount of heat is utilized. Hence, that takes longer duration to evaporate total quantity of water portion from the preparation. After the preparation $11 \%$ of loss of oil in $\mathrm{ml}$ and $9.5 \%$ loss of oil in gms over a period of 55 days is observed and it is having strong smell of Jatamansi suggests imbibement of volatile principle of ingredients into the preparation. When it is analysed it has shown the color of Adityapaka Guduchi Taila looks as rusty orange due to long exposure to the sunlight and presence of Jatamansi as one of the Kalka Dravya. Smell also resembles Jatamansi. Analytical parameters of Adityapaka Guduchi Taila are, Refractive Index is less and Specific gravity more, Acid Value in highly increased, Saponification value is more, Iodine value is more, Rancidity is slightly oxidized due to longer exposure, HPTLC: 8 is Rf value in Short UV and 5 in Long UV and 2 after derivatization suggests all active ingredients imbibed into the preparation with the aid of Aditya Paka Vidhi (Heating through sunlight).

\section{CONCLUSION}

Study shows that Adityapaka (Heating through sunlight) is a Unique method of preparation which differs in all parameters of pharmaceutical as well as Analytical parameters as compared to commonly prepared Taila Kalpana (Agnipaka Vidhi- Heating through Fire). It is time in need to bring light on such different pharmaceutical procedure-based medicine and clinical study on such preparation will reveals the miraculous health benefits. 


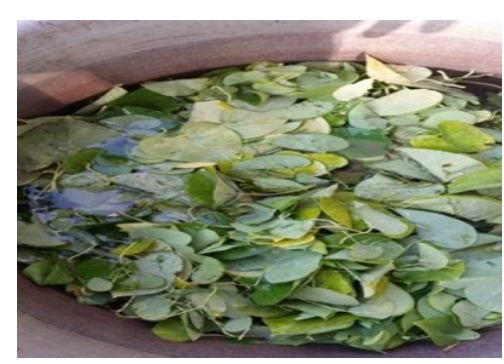

Fig.1: Guduchi Panchanga.

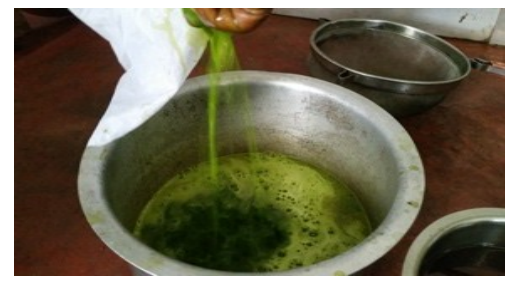

Fig. 4: Guduchi Swarasa

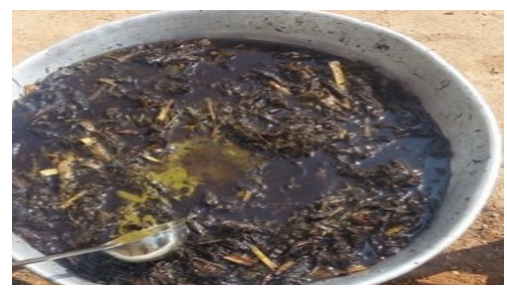

Fig.7: Suspending Mixture;

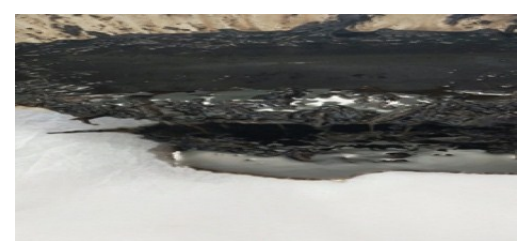

Fig. 10: Collection of APGT; Fig.11: Extraction of APGT

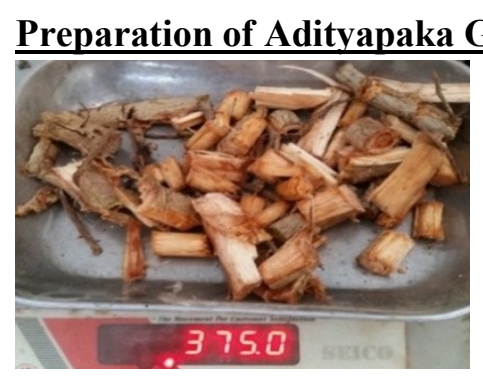

Fig.2: Vata Praroha

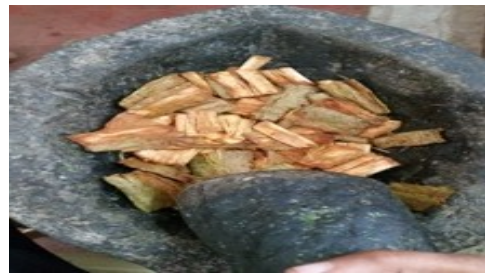

Fig.5: Vata Praroha Kalka

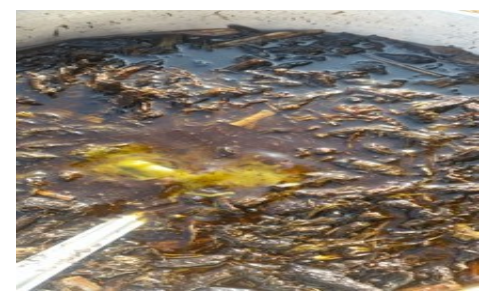

Fig. 8: Constant steering.

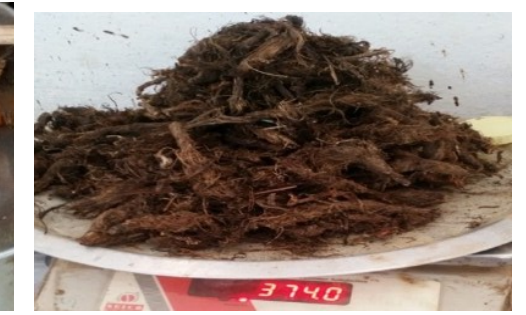

Fig.3: Jatamansi

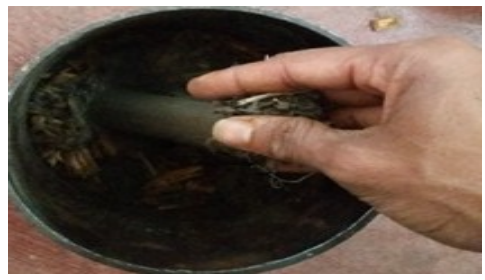

Fig.6: Jatamansi Kalka

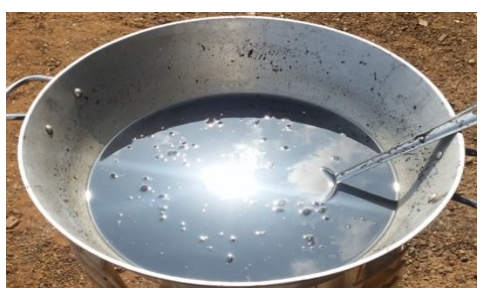

Fig.9: Keeping in Sunlight for 55 days

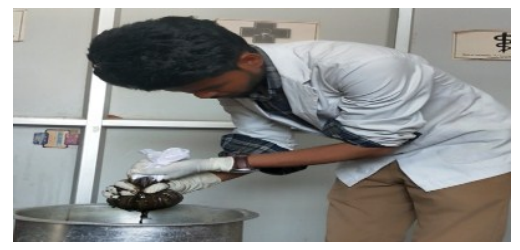

Fig.12: APGT Final Product

Analytical Study:

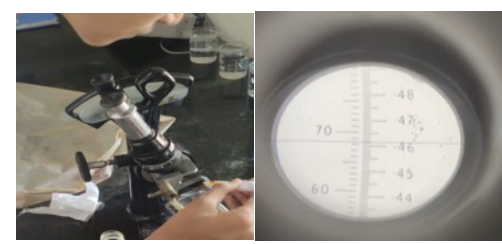

Fig. 13: Refractive Index Test

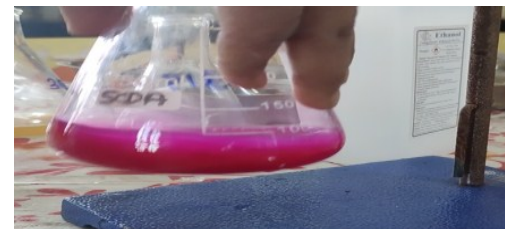

Fig.16 Acid Value Test.

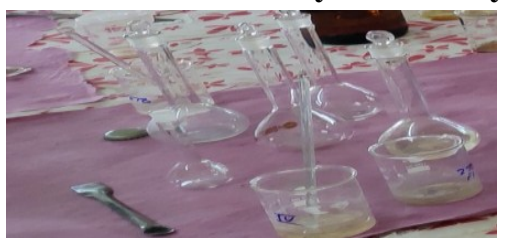

Fig. 14: Specific Gravity Test

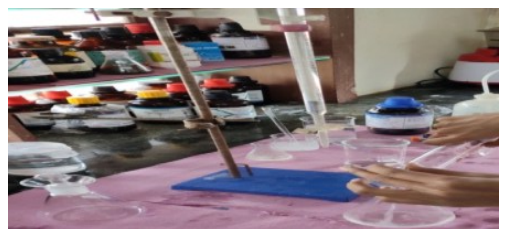

Fig.17: Saponification Test
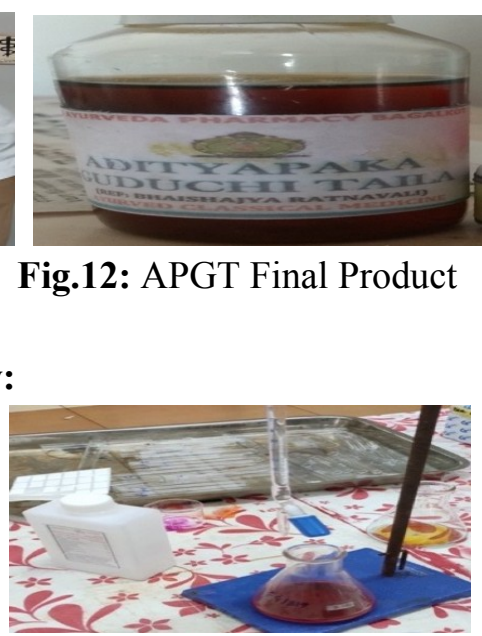

Fig. 15: Iodine Value Test

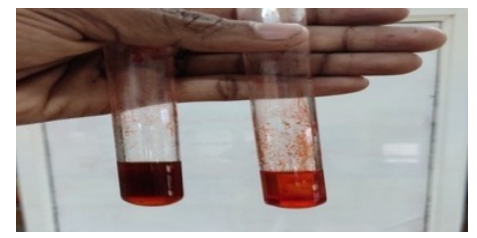

Fig.17: Rancidity Test 

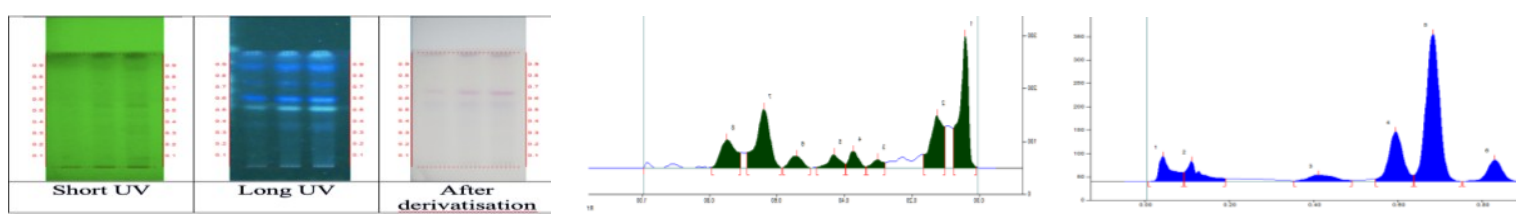

Fig.18: HPTLC and Densitometric Scan (At 254nm and $366 \mathrm{~nm}$ ) photo Document APGT

\section{REFERENCES}

1. Review On Adityapaka - Sneha Kalpana By Rang Sourav Kumar, Unique Journal Of Ayurvedic And Herbal Medicines, ISSN 2347-2375, Rang Et Al. Ujahm 2016, 04 (06): Page 22-24

2. Sri Rajeshwara Data Shasthri "BHAISHAJYA RATNAVALI" with Shri Ambika data shastri Commentary, (Kshudra Rogadhikara 60/146),2004 reprint, Choukamba Samskrita Samsthana Varanashi; Page no. 670

3. Sharangadhara "Sharangadhar Samhita" with dipika and Gudhartha dipika commentary (Madhyam khanda 1/2) edition reprint 2013 Chaukhambha Orientalia Varanasi, page no 137

4. Sharangadhara, "Sharangadhar Samhita" with dipika and Gudhartha Dipika commentary Parashuram Shastry (Madhyam khanda 5/1) edition reprint 2013 Chaukhambha Orientalia Varanasi, page no 176

5. Rama Chandra Reddy, Bhaisajya Kalpana Vijnanam, 2nd ed., Chaukhamba Sanskrit Bhavan, Varanasi P. 389

6. Lohar. D. R., Protocol for Testing Ayurvedic, Siddha \& Unani Medicines. Govt. of India Dept. of AYUSH, Ministry of Health \& Family Welfare, Pharmacopoeial Laboratory For Indian Medicines Ghaziabad. Page 111

7. Lohar. D. R., Protocol for Testing Ayurvedic, Siddha \& Unani Medicines. Govt.of India Dept.of AYUSH, Ministry of Health \& Family Welfare, Pharmacopoeial Laboratory For Indian Medicines Ghaziabad. Page 112

8. Lohar.D.R., Protocol for Testing Ayurvedic, Siddha \& Unani Medicines. Govt.of India Dept.of AYUSH, Ministry of Health \& Family Welfare, Pharmacopoeial Laboratory For Indian Medicines Ghaziabad. Page 124

9. Lohar.D.R., Protocol for Testing Ayurvedic, Siddha \& Unani Medicines. Govt.of India Dept.of AYUSH, Ministry of Health \& Family Welfare, Pharmacopoeial Laboratory For Indian Medicines Ghaziabad. Page 125

10. Lohar.D.R., Protocol for Testing Ayurvedic, Siddha \& Unani Medicines. Govt.of India Dept.of AYUSH, Ministry of Health \& Family Welfare, Pharmacopoeial Laboratory For Indian Medicines Ghaziabad. Page 126

11. Lohar.D.R., Protocol for Testing Ayurvedic, Siddha \& Unani Medicines. Govt.of India Dept.of AYUSH,
Ministry of Health \& Family Welfare, Pharmacopoeial Laboratory For Indian Medicines Ghaziabad. Page 128

12. Lohar. D. R., Protocol for Testing Ayurvedic, Siddha \& Unani Medicines. Govt. of India Dept. of AYUSH, Ministry of Health \& Family Welfare, Pharmacopoeial Laboratory For Indian Medicines Ghaziabad. Page 77

13. Lohar. D. R., Protocol for Testing Ayurvedic, Siddha \& Unani Medicines. Govt.of India Dept.of AYUSH, Ministry of Health \& Family Welfare, Pharmacopoeial Laboratory For Indian Medicines Ghaziabad. Page 114

\section{Source of Support: Nil \\ Conflict of Interest: None Declared}

How to cite this URL: Bankimchandra S. Jambagi \& Vijaykumar Chavadi: Pharmaceutico-Analytical Study Of Adityapaka Guduchitaila W.S.R To Adityapaka Method. International Ayurvedic Medical Journal \{online\} 2020 \{cited September, 2020\} Available from: http://www.iamj.in/posts/images/upload/4411_4417.pdf 